\title{
THE VARIABILITY OF Succisa pratensis Mo en ch INDIVIDUALS AND RAMET CLUSTERS IN ABANDONED Molinietum caeruleae MEADOWS
}

\author{
KINGA KOSTRAKIEWICZ-GIERAŁT
}

Department of Plant Ecology, Institute of Botany, Jagiellonian University, Lubicz 46, 31-512 Kraków, Poland; e-mail: kinga.kostrakiewicz@uj.edu.pl

\begin{abstract}
Kostrakiewicz-Gierałt K.: The variability of Succisa pratensis Moench individuals and ramet clusters in abandoned Molinietum caeruleae meadows. Ekológia (Bratislava), Vol. 34, No. 3, p. 216-225, 2015.

This paper reports the results of observations of the abundance of population Succisa pratensis Moench, as well as temporal and spatial variabilities of chosen traits such as the number of rosettes, number of leaves per rosette, number and height of flowering stems, number of flower heads per generative stem and number of seeds per fruit. Investigations were conducted in the years 2009-2013, in six patches of Molinietum caeruleae with different dominant species, unmanaged from 10 to 22 years. On the basis of studies performed, the state of populations and chances for maintenance in the colonised site were evaluated.
\end{abstract}

Key words: abundance, clonal plant, generative stem, flower head, leaf rosette, seed production, succession.

\section{Introduction}

The abandonment of semi-natural habitats due to economic, structural, as well as social factors results in gradual encroachment of competitively strong species such as non-native perennials, shrubs and trees. The advanced secondary succession leads to undesirable changes of environmental conditions such as diminishing of light availability, as well as increase of biomass and litter accumulation, repeatedly observed in meadows (Burnside et al., 2007; Truus, Puusild, 2009; Rosenthal, 2010; Opdekamp et al., 2009), as well as calcareous grasslands in entire Europe (Poschlod et al., 2002; Hegedüšová, Senko, 2011; Csergő et al., 2013). The transformations of site conditions affect the variability in performance of many species at various scales, both in time and space. The temporal and spatial variabilities were investigated in populations of several perennials with different architecture (Jensen, Meyer, 2001; Bódis, Molnár, 2001; Denisiuk et al., 2009; Chmura et al., 2012; Černá, Münzbergová, 2013; Kostrakiewicz-Gierałt, 2013, 2014).

Analysing the large body of literature, it might be concluded that the majority of investigations have been focused on threatened and protected species, while the observations of rare but not legally protected taxa have been rather neglected. Taking into account the insufficient state of knowledge, the present investigations were performed. The main goal was to 
study the temporal and spatial variabilities in number, size and fecundity of Succisa pratensis individuals and ramet clusters inhabiting Molinietum caeruleae meadows unmanaged from 10 to 22 years and characterising diverse habitat conditions. The specific aims were to examine: (1) the number of individuals, (2) the production and size of vegetative rosettes, (3) the production of generative rosettes, (4) the number and height of generative stems and (5) the production of flower heads and seeds.

\section{Study species}

Devil's-bit Scabious Succisa pratensis Moench (Dipsacaceae) is a perennial herb with a high (for 25 years) genet longevity. The individuals form a short vertical rhizome bearing a rosette of leaves. In August and September, the individuals produce flowering stems, usually carrying a total of up to six, but occasionally more, flower heads with up to 100 small, pale violet flowers. Most seeds land close to the mother plant, but long-distance dispersal by animals or wind is likely to occur. The following developmental stages are distinguished: seedlings with usually 4 leaves, juveniles forming 5-6 rosette leaves, vegetative adults consisting of 6-12 leaves and flowering mature plants with rosette and flowering stalks. Clonal propagation occurs occasionally and it is realised by the production of adventitious buds in stolons. The side rosettes are attached for the first year to the maternal plant (Adams, 1955).

S. pratensis belongs to West European and Middle Siberian plants (Meusel, Jäger, 1992) and occurs in woodland rides, in heathland and grassland and in mires, and in the uplands on cliff ledges and in ravines. As the effect of land abandonment and habitat fragmentation, the number of populations of the above-mentioned species diminished significantly during the last century (Herben et al., 2006). Moreover S. pratensis belongs to a species vulnerable to extinction (VU) in Luxembourg (Colling, 2005) and it is considered as a taxon of least concern (LC) in Great Britain (Cheffings, Farrell, 2002) and Switzerland (Moser et al., 2002). Additionally, it should be mentioned that the diminishing of S. pratensis populations influences the extinction of threatened butterfly Euphydryas aurinia (van Swaay et al., 2013), whose larvae develop on the Devil's-bit Scabious leaves.

\section{Study area}

The investigations were conducted in patches of abandoned Molinietum caeruleae meadows situated in Southern Poland, in Kostrze (patches I-III), Opatkowice (patches IV-V) and Pychowice (patch VI). All patches were characterised by the presence of Betonica officinalis, Dianthus superbus, Galium boreale, Gentiana pneumonanthe, Gladiolus imbricatus, Inula salicina, Iris sibirica, as well as Selinum carvifolia.

Patch I, unmanaged for 10 years and measuring approximately $1400 \mathrm{~m}^{2}$, was dominated by small-tussock grasses such as Briza media, rosette-forb species with erect or procumbent stems, that is, Lychnis flos-cuculi, Lotus corniculatus and Lathyrus pratensis. Patch II has not been used for 13 years and covered an area of $1900 \mathrm{~m}^{2}$; it was prevailed by shrub willow Salix rosmarinifolia. Patch III not managed for 13 years and measuring approximately $1700 \mathrm{~m}^{2}$ was dominated by Salix rosmarinifolia and Phragmites australis. Patch IV abandoned for 15 years and covering an area of $1300 \mathrm{~m}^{2}$, was overgrown by large-tussock grasses such as Deschampsia caespitosa and Molinia caerulaea. Patch V unmanaged for 22 years and measuring approximately $1500 \mathrm{~m}^{2}$, was dominated by Deschampsia caespitosa and Phragmites australis. Patch VI has not been used for 30 years and covered an area $1800 \mathrm{~m}^{2}$; it was prevailed by tallgrowing macroforbs such as Serratula tinctoria, Sanguisorba officinalis, Filipendula ulmaria and Solidago serotina, as well as bushes and trees (i.e., Crataegus sp., Populus tremula, Betula pendula).

In all of the above-mentioned patches, the survey of habitat conditions was performed from 3 to 18 July 2009, from 2 to 15 July 2010, from 5 to 21 July 2011, from 4 to 19 July 2012 and from 2 to 17 July 2013. Each year the percentage of ground surface covered by vascular plants/moss was estimated on the basis of 20 measurements using an aluminium frame $(30 \times 30 \mathrm{~cm})$ in randomly chosen sites within the patch. The average height of vascular plants in the patch was evaluated on the basis of measurements of 20 randomly chosen stems of different species performed using a folding tape measure. The light intensity at the soil surface was surveyed with a digital light meter Voltcraft MS-1300 (accuracy +/- 5\% + 10 digits; measuring range $0.01-50000 \mathrm{~lx}$ ). In total, 10 measurements per patch were taken: five measurements were performed on sunny days and the other five on cloudy ones. A detailed description of the habitat conditions is given in Table 1. 
$\mathrm{T}$ a b l e 1 . The characteristics of habitat conditions in observed patches.

\begin{tabular}{|c|c|c|c|c|c|}
\hline \multirow{2}{*}{ Patch } & \multirow{2}{*}{ Year } & \multicolumn{4}{|c|}{ Mean value of } \\
\hline & & Vascular plant cover (\%) & Moss cover (\%) & Vascular plant height $(\mathrm{cm})$ & Light intensity (lx) \\
\hline \multirow[t]{5}{*}{ I } & 2009 & 96 & 2.0 & 52.9 & 46700 \\
\hline & 2010 & 97 & 2.0 & 55.6 & 44500 \\
\hline & 2011 & 97 & 2.0 & 56.3 & 43100 \\
\hline & 2012 & 97 & 1.5 & 60.6 & 40500 \\
\hline & 2013 & 97 & 1.5 & 62.7 & 37100 \\
\hline \multirow[t]{5}{*}{ II } & 2009 & 97 & 2.0 & 74.3 & 39500 \\
\hline & 2010 & 97 & 2.0 & 78.9 & 38000 \\
\hline & 2011 & 96 & 2.0 & 80.8 & 37000 \\
\hline & 2012 & 97 & 1.0 & 82.1 & 35100 \\
\hline & 2013 & 97 & 1.0 & 84.5 & 32900 \\
\hline \multirow[t]{5}{*}{ III } & 2009 & 97 & 1.5 & 83.1 & 32400 \\
\hline & 2010 & 97 & 1.5 & 87.6 & 30600 \\
\hline & 2011 & 97 & 1.5 & 90.3 & 29600 \\
\hline & 2012 & 97 & 1.0 & 89.0 & 27300 \\
\hline & 2013 & 98 & 1.0 & 90.5 & 24900 \\
\hline \multirow[t]{5}{*}{ IV } & 2009 & 97 & 1.5 & 114.4 & 31300 \\
\hline & 2010 & 98 & 1.5 & 119.4 & 29100 \\
\hline & 2011 & 98 & 1.5 & 123.7 & 27800 \\
\hline & 2012 & 98 & 1.0 & 121.4 & 25200 \\
\hline & 2013 & 98 & 1.0 & 123.9 & 22100 \\
\hline \multirow[t]{5}{*}{$\mathrm{V}$} & 2009 & 98 & 1.5 & 131.4 & 26400 \\
\hline & 2010 & 98 & 1.5 & 135.4 & 24900 \\
\hline & 2011 & 98 & 1.0 & 137.3 & 23200 \\
\hline & 2012 & 98 & 1.0 & 138.9 & 19900 \\
\hline & 2013 & 98 & 1.0 & 140.5 & 17500 \\
\hline \multirow[t]{5}{*}{ VI } & 2009 & 98 & 1.5 & 142.8 & 21600 \\
\hline & 2010 & 98 & 1.5 & 149.6 & 20900 \\
\hline & 2011 & 98 & 1.0 & 152.0 & 19400 \\
\hline & 2012 & 98 & 1.0 & 155.1 & 17100 \\
\hline & 2013 & 98 & 1.0 & 157.5 & 15900 \\
\hline
\end{tabular}

\section{Material and methods}

In each of the aforementioned patches, one population of Succisa pratensis has been established. In the year 2009, in each population the abundance of individuals (defined as a single vegetative or generative rosette) and ramet clusters (understood as an integral group of rosettes) was examined. Subsequently, the representative, permanent study plots $(10 \times 10 \mathrm{~m})$ were set and fenced, whereas all individuals and ramet clusters growing within them were tagged with plastic pegs. During the years 2009-2013 the numbers of individuals and ramet clusters of S. pratensis growing within particular plots were examined. Moreover, in each season the following parameters were counted or measured: (1) number of rosettes in each individual/ramet cluster, (2) number of leaves in each rosette, (3) number of generative rosettes in each individual/ramet cluster, (4) number and height of generative stalks, (5) number of flower heads in each generative stem.

Furthermore, the number of seeds per fruit was surveyed in 30 flower heads randomly collected beyond the study plot. The statistical analysis was based on non-parametric H Kruskal-Wallis test. 


\section{Results}

The total numbers of individuals and ramet clusters of $S$. pratensis in particular patches are $112,102,84,75,97$ and 224, respectively. The gradual, slight increase of abundance in consecutive years was found only in patch I, the constant abundance was recorded in patches II and VI, while the slight decrease of abundance was found in patches III and IV (Table 2). The number of rosettes ranged from 0.90 to 1.84 per genet/ramet cluster and did not show the spatial or the temporal variability (Table 3 ). The number of leaves per rosette amounted from 4.2 to 8.3. It showed only the spatial variability and dropped significantly from patch I, through patches II, III, IV and V, to patch VI (Table 4). The number of generative stems was much lower in patches I, II, III and IV, where it ranged from 1.6 to 3.0, than in patches V and VI, where it ranged from 2.3 to 7.0 In all patches, the number of generative stems increased moderately in consecutive years (Table 5). The height of flowering stems measured from 70.5 $\mathrm{cm}$ to $116.4 \mathrm{~cm}$ and increased in particular patches, as well as in consecutive seasons (Table 6). A similar tendency was present for the number of flower heads, which amounted from 2.4 to 7.8 (Table 7), as well as the seed number, which ranged from 50.5 to 105.8 (Table 8).

$\mathrm{T} \mathrm{a} \mathrm{b} \mathrm{l} \mathrm{e} \mathrm{2.} \mathrm{The} \mathrm{total} \mathrm{number} \mathrm{of} \mathrm{individuals} \mathrm{and} \mathrm{ramet} \mathrm{clusters} \mathrm{of} \mathrm{Succisa} \mathrm{pratensis} \mathrm{Moench} \mathrm{in} \mathrm{permanent} \mathrm{study}$ plots established in particular patches in the years 2009-2013.

\begin{tabular}{|l|l|l|l|l|l|l|}
\hline \multirow{2}{*}{ Year } & \multicolumn{7}{|c|}{ Patch } & VI \\
\cline { 2 - 7 } & I & II & III & IV & 11 & 42 \\
\hline 2009 & 10 & 13 & 17 & 14 & 11 & 42 \\
\hline 2010 & 10 & 13 & 17 & 14 & 11 & 42 \\
\hline 2011 & 11 & 13 & 14 & 13 & 11 & 42 \\
\hline 2012 & 11 & 13 & 14 & 13 & 11 & 42 \\
\hline 2013 & 15 & 13 & 15 & 12 & & V \\
\hline
\end{tabular}

$\mathrm{T} \mathrm{a} \mathrm{b} \mathrm{l} \mathrm{e} \mathrm{3.} \mathrm{The} \mathrm{mean} \mathrm{number} \mathrm{(range)} \mathrm{of} \mathrm{rosettes} \mathrm{per} \mathrm{individual/ramet} \mathrm{cluster} \mathrm{of} \mathrm{Succisa} \mathrm{pratensis} \mathrm{Moench} \mathrm{in} \mathrm{the}$ study plots in the years 2009-2013. The differences between patches and years were not significant $\left({ }^{\mathrm{ns}}\right)$.

\begin{tabular}{|c|c|c|c|c|c|c|c|}
\hline \multirow{2}{*}{ Year } & \multicolumn{6}{|c|}{ Patch } & \multirow{2}{*}{ The $\mathrm{H}$ value } \\
\hline & I & II & III & IV & $\mathrm{V}$ & VI & \\
\hline \multirow{2}{*}{2009} & 1.2 & 1.3 & 1.1 & 1.2 & 1.4 & 1.0 & \multirow{2}{*}{$4.16^{\mathrm{ns}}$} \\
\hline & $(1-2)$ & $(1-3)$ & $(1-2)$ & $(1-2)$ & $(1-3)$ & $(0-2)$ & \\
\hline \multirow{2}{*}{2010} & 1.4 & 1.1 & 1.2 & 1.1 & 0.9 & 0.9 & \multirow{2}{*}{$9.19^{\text {ns }}$} \\
\hline & $(1-2)$ & $(1-3)$ & $(1-4)$ & $(1-2)$ & $(0-3)$ & $(0-2)$ & \\
\hline \multirow{2}{*}{2011} & 1.6 & 1.4 & 1.1 & 1.0 & 1.1 & 1.0 & \multirow{2}{*}{$7.50^{\mathrm{ns}}$} \\
\hline & $(1-3)$ & $(1-3)$ & $(1-2)$ & $(1-2)$ & $(0-4)$ & $(0-2)$ & \\
\hline \multirow{2}{*}{2012} & 1.7 & 1.6 & 1.3 & 1.2 & 1.6 & 1.0 & \multirow{2}{*}{$11.76^{\mathrm{ns}}$} \\
\hline & $(1-3)$ & $(1-3)$ & $(1-2)$ & $(1-2)$ & $(0-4)$ & $(0-9)$ & \\
\hline \multirow{2}{*}{2013} & 1.6 & 1.8 & 1.1 & 1.0 & 2.1 & 1.1 & \multirow{2}{*}{$15.56^{\mathrm{ns}}$} \\
\hline & $(1-3)$ & $(1-3)$ & $(1-2)$ & $(1-2)$ & $(0-5)$ & $(0-4)$ & \\
\hline The $\mathrm{H}$ value & $2.89^{\text {ns }}$ & $9.21^{\text {ns }}$ & $3.73^{\text {ns }}$ & $4.34^{\mathrm{ns}}$ & $4.90^{\mathrm{ns}}$ & $0.87^{\text {ns }}$ & \\
\hline
\end{tabular}


$\mathrm{T}$ a b l e 4. The mean number (range) of leaves per rosette of Succisa pratensis Moench in study plots in the years 2009-2013. The statistical significance level: ${ }^{\text {ns }}$ - not significant, ${ }^{*} \mathrm{P} \leq 0.05,{ }^{* *} \mathrm{P}<0.01$ and ${ }^{* *} \mathrm{P}<0.001$.

\begin{tabular}{|c|c|c|c|c|c|c|c|}
\hline \multirow{2}{*}{ Year } & \multicolumn{6}{|c|}{ Patch } & \multirow{2}{*}{ The H value } \\
\hline & I & II & III & IV & $\mathrm{V}$ & VI & \\
\hline 2009 & $\begin{array}{c}8.3 \\
(5-11)\end{array}$ & $\begin{array}{c}6.2 \\
(3-12)\end{array}$ & $\begin{array}{c}5.9 \\
(5-15)\end{array}$ & $\begin{array}{c}5.8 \\
(3-8)\end{array}$ & $\begin{array}{c}4.9 \\
(3-7)\end{array}$ & $\begin{array}{c}5.0 \\
(3-8)\end{array}$ & $26.39^{* *}$ \\
\hline 2010 & $\begin{array}{c}7.9 \\
(5-12)\end{array}$ & $\begin{array}{c}6.1 \\
(5-12)\end{array}$ & $\begin{array}{c}6.0 \\
(4-14)\end{array}$ & $\begin{array}{c}5.5 \\
(3-8)\end{array}$ & $\begin{array}{c}5.1 \\
(4-7)\end{array}$ & $\begin{array}{c}5.2 \\
(3-8)\end{array}$ & $19.70^{*}$ \\
\hline 2011 & $\begin{array}{c}7.6 \\
(4-12)\end{array}$ & $\begin{array}{c}5.1 \\
(4-8)\end{array}$ & $\begin{array}{c}5.0 \\
(4-8)\end{array}$ & $\begin{array}{c}4.7 \\
(3-9)\end{array}$ & $\begin{array}{c}4.5 \\
(4-7)\end{array}$ & $\begin{array}{c}4.9 \\
(3-8)\end{array}$ & $22.74^{* *}$ \\
\hline 2012 & $\begin{array}{c}7.2 \\
(5-10) \\
\end{array}$ & $\begin{array}{c}5.0 \\
(3-6) \\
\end{array}$ & $\begin{array}{c}5.0 \\
(3-8) \\
\end{array}$ & $\begin{array}{c}4.7 \\
(3-9) \\
\end{array}$ & $\begin{array}{c}4.1 \\
(3-6) \\
\end{array}$ & $\begin{array}{c}4.4 \\
(3-7) \\
\end{array}$ & $36.23^{* * *}$ \\
\hline 2013 & $\begin{array}{c}6.0 \\
(3-9)\end{array}$ & $\begin{array}{c}4.9 \\
(4-8) \\
\end{array}$ & $\begin{array}{c}4.8 \\
(3-8) \\
\end{array}$ & $\begin{array}{c}4.5 \\
(4-5) \\
\end{array}$ & $\begin{array}{c}4.0 \\
(3-6) \\
\end{array}$ & $\begin{array}{c}4.2 \\
(3-7) \\
\end{array}$ & $62.83^{* * *}$ \\
\hline The $\mathrm{H}$ value & $5.85^{\mathrm{ns}}$ & $12.39^{\text {ns }}$ & $3.62^{\mathrm{ns}}$ & $9.81^{\mathrm{ns}}$ & $10.85^{\mathrm{ns}}$ & $17.49^{* *}$ & \\
\hline
\end{tabular}

$\mathrm{T}$ a b le 5. The mean number (range) of generative stems per individual/ramet cluster of Succisa pratensis Mo ench in study plots in the years 2009-2013. The statistical significance level is as in Table 4.

\begin{tabular}{|c|c|c|c|c|c|c|c|}
\hline \multirow{2}{*}{ Year } & \multicolumn{6}{|c|}{ Patch } & \multirow{2}{*}{ The $\mathrm{H}$ value } \\
\hline & I & II & III & IV & $\mathrm{V}$ & VI & \\
\hline 2009 & $\begin{array}{c}1.6 \\
(1-2)\end{array}$ & $\begin{array}{c}1.5 \\
(1-3)\end{array}$ & $\begin{array}{c}1.9 \\
(1-4)\end{array}$ & $\begin{array}{c}1.6 \\
(1-2)\end{array}$ & $\begin{array}{c}4.9 \\
(2-8)\end{array}$ & $\begin{array}{c}2.3 \\
(1-7)\end{array}$ & $27.06^{* *}$ \\
\hline 2010 & $\begin{array}{c}1.7 \\
(1-3)\end{array}$ & $\begin{array}{c}1.6 \\
(1-4)\end{array}$ & $\begin{array}{c}2.2 \\
(1-5)\end{array}$ & $\begin{array}{c}1.57 \\
(1-2)\end{array}$ & $\begin{array}{c}6.0 \\
(3-10)\end{array}$ & $\begin{array}{c}2.6 \\
(1-12)\end{array}$ & $27.96^{* *}$ \\
\hline 2011 & $\begin{array}{c}1.7 \\
(0-3)\end{array}$ & $\begin{array}{c}2.8 \\
(1-6)\end{array}$ & $\begin{array}{c}1.4 \\
(1-2)\end{array}$ & $\begin{array}{c}1.7 \\
(1-5)\end{array}$ & $\begin{array}{c}6.8 \\
(4-14)\end{array}$ & $\begin{array}{c}2.9 \\
(1-10)\end{array}$ & $30.83^{* * *}$ \\
\hline 2012 & $\begin{array}{c}1.9 \\
(1-3)\end{array}$ & $\begin{array}{c}3.0 \\
(1-6)\end{array}$ & $\begin{array}{c}2.6 \\
(1-4) \\
\end{array}$ & $\begin{array}{c}2.9 \\
(1-5) \\
\end{array}$ & $\begin{array}{c}7.0 \\
(3-14) \\
\end{array}$ & $\begin{array}{c}3.2 \\
(1-14)\end{array}$ & $24.99^{* *}$ \\
\hline 2013 & $\begin{array}{c}1.80 \\
(0-4) \\
\end{array}$ & $\begin{array}{c}3.15 \\
(1-6) \\
\end{array}$ & $\begin{array}{c}3.0 \\
(0-6)\end{array}$ & $\begin{array}{c}3.75 \\
(2-9) \\
\end{array}$ & $\begin{array}{c}6.45 \\
(3-10) \\
\end{array}$ & $\begin{array}{c}3.47 \\
(1-14)\end{array}$ & $27.75^{* * *}$ \\
\hline The $\mathrm{H}$ value & $0.43^{\mathrm{ns}}$ & $16.10^{*}$ & $16.79^{*}$ & $21.72^{\star *}$ & $3.31^{\mathrm{ns}}$ & $0.76^{\mathrm{ns}}$ & \\
\hline
\end{tabular}

$\mathrm{T}$ a b l e 6. The mean (range) of height of generative stems $(\mathrm{cm})$ of Succisa pratensis Moench in study plots in the years 2009-2013. The statistical significance level is as in Table 4.

\begin{tabular}{|c|c|c|c|c|c|c|c|}
\hline \multirow{2}{*}{ Year } & \multicolumn{6}{|c|}{ Patch } & \multirow{2}{*}{ The $\mathrm{H}$ value } \\
\hline & I & II & III & IV & $\mathrm{V}$ & VI & \\
\hline 2009 & $\begin{array}{c}70.5 \\
(45-108)\end{array}$ & $\begin{array}{c}73.8 \\
(46-111)\end{array}$ & $\begin{array}{c}87.6 \\
(58-121)\end{array}$ & $\begin{array}{c}91.0 \\
(52-130)\end{array}$ & $\begin{array}{c}99.7 \\
(73-134)\end{array}$ & $\begin{array}{c}100.2 \\
(69-128)\end{array}$ & $64.56^{* * *}$ \\
\hline 2010 & $\begin{array}{c}73.7 \\
(45-112) \\
\end{array}$ & $\begin{array}{c}79.4 \\
(67-119) \\
\end{array}$ & $\begin{array}{c}90.1 \\
(72-121)\end{array}$ & $\begin{array}{c}100.0 \\
(59-128)\end{array}$ & $\begin{array}{c}107.32 \\
(78-148)\end{array}$ & $\begin{array}{c}106.9 \\
(70-136) \\
\end{array}$ & $81.59^{* * *}$ \\
\hline 2011 & $\begin{array}{c}75.1 \\
(37-113)\end{array}$ & $\begin{array}{c}80.6 \\
(48-103)\end{array}$ & $\begin{array}{c}86.5 \\
(70-97)\end{array}$ & $\begin{array}{c}103.1 \\
(42-130)\end{array}$ & $\begin{array}{c}111.5 \\
(74-153)\end{array}$ & $\begin{array}{c}110.7 \\
(61-159) \\
\end{array}$ & $78.13^{* * *}$ \\
\hline 2012 & $\begin{array}{c}78.8 \\
(49-117)\end{array}$ & $\begin{array}{c}85.7 \\
(47-124)\end{array}$ & $\begin{array}{c}94.5 \\
(46-118)\end{array}$ & $\begin{array}{c}101.7 \\
(74-131)\end{array}$ & $\begin{array}{c}113.1 \\
(78-153)\end{array}$ & $\begin{array}{c}112.9 \\
(69-144)\end{array}$ & $94.96^{* * *}$ \\
\hline 2013 & $\begin{array}{c}79.4 \\
(43-99)\end{array}$ & $\begin{array}{c}88.2 \\
(48-129)\end{array}$ & $\begin{array}{c}95.4 \\
(79-132)\end{array}$ & $\begin{array}{c}114.7 \\
(89-139)\end{array}$ & $\begin{array}{c}115.7 \\
(89-153)\end{array}$ & $\begin{array}{c}116.4 \\
(52-148)\end{array}$ & $133.34^{\star * *}$ \\
\hline The $\mathrm{H}$ value & $4.65^{\mathrm{ns}}$ & $11.96^{*}$ & $25.78^{\star * *}$ & $28.01^{\star * *}$ & $37.96^{* * *}$ & $53.61^{* * *}$ & \\
\hline
\end{tabular}


$\mathrm{T}$ a b l e 7. The mean number (range) of flower heads per generative stems of Succisa pratensis Moench in study plots in the years 2009-2013. The statistical significance level is as in Table 4.

\begin{tabular}{|c|c|c|c|c|c|c|c|}
\hline \multirow{2}{*}{ Year } & \multicolumn{6}{|c|}{ Patch } & \multirow{2}{*}{ The $\mathrm{H}$ value } \\
\hline & I & II & III & IV & $\mathbf{V}$ & VI & \\
\hline 2009 & $\begin{array}{c}2.4 \\
(1-7)\end{array}$ & $\begin{array}{c}2.8 \\
(1-4)\end{array}$ & $\begin{array}{c}3.3 \\
(2-7)\end{array}$ & $\begin{array}{c}3.8 \\
(1-8)\end{array}$ & $\begin{array}{c}5.8 \\
(3-11) \\
\end{array}$ & $\begin{array}{c}6.2 \\
(2-10) \\
\end{array}$ & $91.42^{* * *}$ \\
\hline 2010 & $\begin{array}{c}2.5 \\
(1-7) \\
\end{array}$ & $\begin{array}{c}3.0 \\
(2-7)\end{array}$ & $\begin{array}{c}3.5 \\
(1-7) \\
\end{array}$ & $\begin{array}{c}4.1 \\
(1-8)\end{array}$ & $\begin{array}{c}6.9 \\
(3-15) \\
\end{array}$ & $\begin{array}{c}6.4 \\
(2-13)\end{array}$ & $100.84^{* * *}$ \\
\hline 2011 & $\begin{array}{c}2.6 \\
(1-6)\end{array}$ & $\begin{array}{c}3.1 \\
(1-5)\end{array}$ & $\begin{array}{c}3.7 \\
(1-7)\end{array}$ & $\begin{array}{c}4.6 \\
(1-10)\end{array}$ & $\begin{array}{c}7.3 \\
(3-15)\end{array}$ & $\begin{array}{c}6.7 \\
(3-15)\end{array}$ & $109.46^{* * *}$ \\
\hline 2012 & $\begin{array}{c}2.6 \\
(1-6)\end{array}$ & $\begin{array}{c}3.2 \\
(1-5) \\
\end{array}$ & $\begin{array}{c}4.0 \\
(1-7)\end{array}$ & $\begin{array}{c}4.8 \\
(1-10) \\
\end{array}$ & $\begin{array}{c}7.5 \\
(3-16) \\
\end{array}$ & $\begin{array}{c}7.3 \\
(3-17) \\
\end{array}$ & $141.19^{* * *}$ \\
\hline 2013 & $\begin{array}{c}2.8 \\
(1-7) \\
\end{array}$ & $\begin{array}{c}3.5 \\
(1-5) \\
\end{array}$ & $\begin{array}{c}3.6 \\
(1-11) \\
\end{array}$ & $\begin{array}{c}5.3 \\
(1-7) \\
\end{array}$ & $\begin{array}{c}7.7 \\
(3-17) \\
\end{array}$ & $\begin{array}{c}7.8 \\
(3-15) \\
\end{array}$ & $171.74^{\star * \star}$ \\
\hline The $\mathrm{H}$ value & $2.83^{\mathrm{ns}}$ & $6.22^{\mathrm{ns}}$ & $29.09^{* *}$ & $10.16^{*}$ & $18.37^{* *}$ & $16.58^{\star *}$ & \\
\hline
\end{tabular}

T a b l e 8. The mean number (range) of seeds in 30 flower heads of Succisa pratensis Moench sampled from study plots in the years 2009-2013. The statistical significance level is as in Table 4.

\begin{tabular}{|c|c|c|c|c|c|c|c|}
\hline \multirow{2}{*}{ Year } & \multicolumn{6}{|c|}{ Patch } & \multirow{2}{*}{ The $\mathrm{H}$ value } \\
\hline & I & II & III & IV & V & VI & \\
\hline 2009 & $\begin{array}{c}50.4 \\
(27-88)\end{array}$ & $\begin{array}{c}52.9 \\
(25-85) \\
\end{array}$ & $\begin{array}{c}80.8 \\
(46-128) \\
\end{array}$ & $\begin{array}{c}87.6 \\
(68-123) \\
\end{array}$ & $\begin{array}{c}90.7 \\
(69-118) \\
\end{array}$ & $\begin{array}{c}92.4 \\
(60-119) \\
\end{array}$ & $93.01^{* * *}$ \\
\hline 2010 & $\begin{array}{c}54.6 \\
(26-90) \\
\end{array}$ & $\begin{array}{c}57.5 \\
(32-98) \\
\end{array}$ & $\begin{array}{c}85.3 \\
(56-129) \\
\end{array}$ & $\begin{array}{c}92.9 \\
(78-115) \\
\end{array}$ & $\begin{array}{c}95.2 \\
(70-127) \\
\end{array}$ & $\begin{array}{c}93.5 \\
(53-115) \\
\end{array}$ & $85.57^{\star * *}$ \\
\hline 2011 & $\begin{array}{c}58.5 \\
(18-93) \\
\end{array}$ & $\begin{array}{c}67.8 \\
(30-110) \\
\end{array}$ & $\begin{array}{c}90.7 \\
(75-142) \\
\end{array}$ & $\begin{array}{c}97.5 \\
(83-115)\end{array}$ & $\begin{array}{c}94.3 \\
(68-136) \\
\end{array}$ & $\begin{array}{c}96.6 \\
(66-122) \\
\end{array}$ & $71.69^{* * *}$ \\
\hline 2012 & $\begin{array}{c}61.5 \\
(25-99) \\
\end{array}$ & $\begin{array}{c}74.5 \\
(43-125) \\
\end{array}$ & $\begin{array}{c}93.4 \\
(62-135) \\
\end{array}$ & $\begin{array}{c}98.0 \\
(83-121) \\
\end{array}$ & $\begin{array}{c}99.2 \\
(71-139) \\
\end{array}$ & $\begin{array}{c}101.8 \\
(82-120) \\
\end{array}$ & $67.81^{\star * *}$ \\
\hline 2013 & $\begin{array}{c}65.1 \\
(32-110)\end{array}$ & $\begin{array}{c}77.3 \\
(35-128)\end{array}$ & $\begin{array}{c}94.3 \\
(68-136)\end{array}$ & $\begin{array}{c}101.3 \\
(88-134)\end{array}$ & $\begin{array}{c}102.7 \\
(77-143)\end{array}$ & $\begin{array}{c}105.8 \\
(78-137)\end{array}$ & $74.90^{* * *}$ \\
\hline The H value & $10.71^{\star}$ & $30.16^{* * *}$ & $8.55^{\mathrm{ns}}$ & $20.81^{\star *}$ & $8.13^{\mathrm{ns}}$ & $13.05^{\star}$ & \\
\hline
\end{tabular}

\section{Discussion}

The performed observations showing that the differences in size of populations are not correlated with the period of abandonment are in opposition to several studies reported by Plieninger et al. (2013). Simultaneously, it should be pointed out that several authors claimed that the size of $S$. pratensis populations does not affect the performance of individuals (Hooftman et al., 2003) and genetic diversity (Billeter et al., 2002). On the other hand, Vergeer et al. (2003a, b) bring evidence that genets originating from smaller populations performed less well, showed less genetic variation and higher inbreeding coefficients than plants from large populations. Furthermore, according to the aforementioned authors, plants from small populations suffered more from deteriorating soil conditions than those from large populations.

The presented results showing the successive, slight increase of abundance only in patches dominated by small meadow species might be due to the appearance of openings in con- 
tinuous plant cover considered as safe sites for seedling recruitment. Such a phenomenon is consistent with the studies of Wallin (2007), who claimed that in the meadows both the mowing and raking treatments resulted in higher population growth rates compared to the unmanaged plots. Also, Bühler and Schmid (2001) found that mowing and grazing contribute to an increase in local densities of seedlings and vegetative adults of S. pratensis. On the other hand, the experiment performed by Jongejans et al. (2006) showed that removal of top soil and seed addition did not contribute to the augmentation of appearance of seedlings of S. pratensis.

The state number of rosettes noted in subsequent patches and consecutive years corresponds with the studies of ramet dynamics in populations of Senecio rivularis performed by Czarnecka $(2008,2011)$. During long-lasting observations the aforementioned author documented that, irrespective of habitat conditions the numbers of ramets per genet and per study patch are rather constant. Simultaneously, it should be pointed out, that the lack of temporal and spatial variabilities of the number of rosettes in populations of Succisa pratensis is not consistent with several investigations. Chaloupecká and Lepš (2004) documented greater proliferation of ramets in genets of Lychnis flos-cuculi and Myosotis nemorosa in gaps in continuous plant cover, than in dense stands. Moreover, the negative influence of the neighbourhood of shrubs and tall-growing macroforbs with robust underground organs on vegetative multiplication was observed in Potentilla anserina (Eriksson, 1985), Ranunculus reptans (van Kleunen et al., 2001), Hieracium pilosella (Winkler, Stöklin, 2002) and Serratula tinctoria (Kostrakiewicz-Gierałt, Bąba, 2014).

The decrease of the number of leaves in rosettes along the gradient of the rising height of plant cover might be caused by the diminishing of light intensity at the soil surface. A similar phenomenon was recorded in individuals of Arabidopsis thaliana growing in artificially induced shade (Cookson, Granier, 2006). The above-mentioned authors argued that a low level of light availability might dramatically reduce the rate of leaf initiation and the duration of the phase of leaf production. Simultaneously, it should be added that an increase of leaf number with augmentation of light availability was recorded in numerous species inhabiting a wide spectrum of habitats from dry sand prairies (Davis et al., 1995), via meadows (Chaloupecká, Lepš, 2004), to forests (Meekins, McCarty, 2000).

The obtained results demonstrating the temporal and spatial variabilities in number and height of flowering stems did not support observations carried out in populations of other taxa occurring in Molinietum caeruleae meadows. In populations of Trollius europaeus, the number of generative stalks did not change significantly in time and in space, while the height of generative stems presented only the spatial variability (Kostrakiewicz, 2009). Also, in populations of Gentiana pneumonanthe (Kostrakiewicz-Gierałt, 2013), Gladiolus imbricatus (KostrakiewiczGierałt, 2014) and Iris sibirica (Kostrakiewicz, 2008), dimensions of generative stems did not change in consecutive years and increased substantially along the gradient of the rising level of shading. The increase of height of generative stalks in the vicinity of tall-growing plants was also recorded in populations of Serratula tinctoria (Kostrakiewicz-Gierałt, Bąba, 2014), Dactylorhiza majalis (Janečková, 2006), as well as D. incarnata (Schrautzer et al., 2011).

The presented studies showing the greatest production of flower heads and seeds in sites with a low level of light intensity are consistent with the findings of van der Meer et al. (2013). 
The aforementioned authors documented that populations of Succisa pratensis growing in abandoned sites have a higher flowering frequency and higher seed set per flower head than populations established in the managed patches. The increase of fruit and seed production along the gradient of growing shading was observed in populations of Serratula tinctoria (Kostrakiewicz-Gierałt, Bąba, 2014).

In the light of the performed investigations, it might be concluded that the population inhabiting the patch prevailed by tall-growing macroforbs, bushes and trees presents the best condition. Constant and high abundance, substantial production of generative rosettes, flowering stems, flower heads and seeds might contribute to persistence in the occupied place, as well as to dispersal to other habitats. The population growing in the patch dominated by small meadow taxa shows a good state as an effect of great abundance and increase of individual numbers despite the lowest number of generative stems, flower heads and seeds. The population inhabiting the meadow prevailed by shrub willows, as well as the population established in the site dominated by large-tussock grasses and common reed present the worse condition because of the low numbers of genets and ramet clusters, generative stems, flower heads and seeds. The population established in the patch overgrown by shrub willows and common reed, as well as the population in the meadow prevailed by large-tussock grasses show an unsatisfactory state due to the lowest and gradually decreasing abundance, as well as the low number of generative stems, flower heads and seeds.

\section{References}

Adams, A. (1955). W. Succisa pratensis Moench. (Scabiosa succisa L.). J. Ecol., 43(2), 709-718. DOI: 10.2307/2257031. Billeter, R., Schneiller, J. \& Diemer M. (2002). Genetic diversity of Carex davalliana and Succisa pratensis in mown and abandoned fen meadows. Bull. Geobot. Inst. ETH, 68, 45-54.

Bódis, J. \& Molnár E. (2009). Long-term monitoring of Himantoglossum adriaticum H. Baumann population in Keszthely Hills, Hungary. Natura Somogyiensis, 15, 27-40.

Bühler, Ch. \& Schmid B. (2001). The influence of management regime and altitude on the population structure of Succisa pratensis: implications for vegetation monitoring. J. Appl. Ecol., 38(4), 689-698. DOI: 10.1046/j.13652664.2001.00640.x.

Burnside, N.G., Joyce, C.B., Puurmann, E. \& Scott D.M. (2007). Use of vegetation classification and plant indicators to assess grazing abandonment in Estonian coastal wetlands. J. Veg. Sci., 18, 645-654. DOI: 10.1111/j.16541103.2007.tb02578.x.

Černá, L. \& Münzbergová Z. (2013). Comparative population dynamics of two closely related species differing in ploidy level. PLoS ONE, 8(10), e75563. DOI: 10.1371/journal.pone.0075563.

Chaloupecká, E. \& Lepš J. (2004). Equivalence of competitor effects and tradeoff between vegetative multiplication and generative reproduction: case study with Lychnis flos-cuculi and Myosotis nemorosa. Flora, 199, 157-167. DOI: $10.1078 / 0367-2530-00144$.

Cheffings, Ch.M. \& Farrell L. (Eds.) (2002). The vascular plant red data list for Great Britain. Species Status. Peterborough: Joint Nature Conservation Committee.

Chmura, D., Adamski, P. \& Denisiuk Z. (2012). Spatiotemporal aspects of the occurrence of clonal steppe plant Adonis vernalis L. in the southern Poland. Časopis Slezského Zemského Muzea (A), 61, 245-250.

Colling, G. (2005). Red list of vascular plants of Luxembourg. Ferrantia, 42, 1-77.

Cookson, S.J. \& Granier Ch. (2006). A dynamic analysis of the shade-induced plasticity in Arabidopsis thaliana rosette leaf development reveals new components of the shade-adaptative response. Ann. Bot., 97(3), 443-452. DOI: $10.1093 / \mathrm{aob} / \mathrm{mcj} 047$.

Csergő, A.M., Demeter, L. \& Turkington R. (2013). Declining diversity in abandoned grasslands of the Carpathian Mountains: Do dominant species matter? PLoS ONE, 8(8), e73533. DOI: 10.1371/journal.pone.0073533.

Czarnecka, B. (2008). Spatiotemporal patterns of genets and ramets in a population of clonal perennial Senecio 
rivularis: plant features and habitat effects. Ann. Bot. Fenn., 45(1), 19-32.

Czarnecka, B. (2011). Formation and dynamics of the metapopulation of Senecio rivularis (Waldst. \& Kit.) DC (Asteraceae) at the limit of its geographical range: where, when, by what means? Pol. J. Ecol., 59(2), 236-278.

Davis, M.A., Ritchie, B., Graf, N. \& Gregg K. (1995). An experimental study of the effects of shade, conspecific crowding, pocket gophers and surrounding vegetation on survivorship, growth and reproduction in Penstemon grandiflorus. Am. Midl. Nat., 134, 237-243.

Denisiuk, Z., Chmura, D. \& Adamski P. (2009). Flowering and generative reproduction in small, isolated populations of endangered monocarpic perennial Carlina onopordifolia Besser (Asteraceae) in Poland. Pol. J. Ecol., $57(1), 89-97$.

Eriksson, O. (1985). Reproduction and clonal growth in Potentilla anserina L. (Rosaceae): the relation between growth form and dry weight allocation. Oecologia, 66(3), 378-380. DOI: 10.1007/BF00378302.

Hegedüšová, K. \& Senko D. (2011). Successional changes of dry grasslands in southwestern Slovakia after 46 years of abandonment. Plant Biosyst., 145(3), 666-687. DOI: 10.1080/11263504.2011.601605.

Herben, T., Münzbergová, Z., Mildén, M., Ehrlèn, J., Cousins, S. \& Eriksson O. (2006). Long-term spatial dynamics of Succisa pratensis in a changing rural landscape: linking dynamical modelling with historical maps. J. Ecol., 94(1), 131-143. http://www.jstor.org/stable/3599616

Hooftman, D.A.P., van Kleunen, M. \& Diemer M. (2003). Effects of habitat fragmentation on the fitness of two common wetland species, Carex davalliana and Succisa pratensis. Oecologia, 134, 350-359. DOI: 10.1007/s00442002-1096-0.

Janečková, P., Votavová, K., Schödelbauerová, I., Jersáková, J. \& Kindlmann P. (2006). Relative effects of management and environmental conditions on performance and survival of populations of a terrestrial orchid, Dactylorhiza majalis. Biol. Conserv., 129, 40-49. DOI: 10.1016/j.biocon.2005.09.045.

Jensen, K. \& Meyer C. (2001). Effects of light competition and litter on the performance of Viola palustris and on species composition and diversity of an abandoned fen meadow. Plant Ecol., 155(2), 169-181. DOI: 10.1023/A:1013270628964.

Jongejans, E., Soons, M.B. \& de Kroon H. (2006). Bottlenecks and spatiotemporal variation in the sexual reproduction pathway of perennial meadow plants. Basic and Applied Ecology, 7(1), 71-81. DOI: 10.1016/j.baae.2005.04.004.

Kostrakiewicz, K. (2008). Population structure of a clonal endangered plant species Iris sibirica L. in different habitat conditions. Pol. J. Ecol., 56(4), 581-592.

Kostrakiewicz, K. (2009). The influence of shadow created by adjacent plants on phenotypic plasticity of endangered species Trollius europaeus L. (Ranunculaceae). Pol. J. Ecol., 57(4), 625-634.

Kostrakiewicz-Gierałt, K. (2013). The effect of vegetation character on abundance of subpopulations of rare herb species Gentiana pneumonanthe L. Pol. J. Ecol., 61(1), 35-43.

Kostrakiewicz-Gierałt, K. (2014). The variability of selected features of Gladiolus imbricatus L. in relation to successive stages of meadow communities following the mowing cessation. Pol. J. Ecol., 62(2), 307-321.

Kostrakiewicz-Gierałt, K. \& Bąba W. (2014). The influence of standing vegetation height on the reproductive allocation in populations of Serratula tinctoria L. Pol. J. Ecol., 62(1), 89-99.

Meekins, J.F. \& McCarty B.C. (2000). Responses of the biennial forest herb Alliaria petiolata to variation in population density, nutrient addition and light availability. J. Ecol., 88(3), 447-463. http://www.jstor.org/stable/2648451

Meusel, H. \& Jäger E.J. (1992). Vergleichende chorologie der zentraleuropäischen flora. Vol. 3. Jena: Gustav Fisher.

Moser, D.M., Gygax, A., Bäumler, B., Wyler, N. \& Palese R. (2002). Rote Liste der gefährdeten Farn- und Blütenpflanzen der Schweiz. Hrsg. Bundesamt für Umwelt, Wald und Landschaft, Bern, Zentrum des Datenverbundnetzes der Schweizer Flora, Chambésy, Conservatoire et Jardin botaniques de la Ville de Genève Chambésy. BUWALReihe „Vollzug Umwelt“.

Opdekamp, W., Beauchard, O., Backx, H., Franken, F., Cox, T.J.S., van Diggelen, R. \& Meire P. (2009). Effects of mowing cessation and hydrology on plant trait distribution in natural fen meadows. Acta Oecol., 39, 117-127. DOI: $10.1016 /$ j.actao.2012.01.011.

Plieninger, T., Gaertner, M., Hui, C. \& Huntsinger L. (2013). Does land abandonment decrease species richness and abundance of plants and animals in Mediterranean pastures, arable lands and permanent croplands? Environmental Evidence, 2, 3. DOI: 10.1186/2047-2382-2-3.

Poschlod, P., Wallis DeVries, M.F. (2002). The historical and socioeconomic perspective of calcareous grasslands lessons from the distant and recent past. Biol. Conserv., 104(3), 361-376. DOI:10.1016/S0006-3207(01)00201-4

Rosenthal, G. (2010). Secondary succession in a fallow central European wet grassland. Flora, 205, 153-160. DOI: 10.1016/j.flora.2009.02.003. 
Schrautzer, J., Fichtner, A., Huckaufa, A., Rasran, L. \& Jensen K. (2011). Long-term population dynamics of Dactylorhiza incarnata (L.) Soó after abandonment and re-introduction of mowing. Flora, 206, 622-630. DOI: 10.1016/j.flora.2010.11.008.

Truus, L. \& Puusild E. (2009). Species richness, biomass production and recent vegetation changes of Estonian floodplain grasslands. Pol. J. Ecol., 57, 33-45.

van der Meer, S., Dahlgren, J.P., Mildén, M. \& Ehrlén J. (2014). Differential effects of abandonment on the demography of the grassland perennial Succisa pratensis. Popul. Ecol., 56, 151-160. DOI: 10.1007/s10144-013-0400-7.

van Kleunen, M., Fischer, M. \& Schmid B. (2001). Effects of intraspecific competition on size variation and reproductive allocation in a clonal plant. Oikos, 94(3), 515-524. DOI: 10.1034/j.1600-0706.2001.940313.x.

van Swaay, C., Wynhoff, I., Verovnik, R., Wiemers, M., López Munguira, M., Maes, D., Sasic, M., Verstrael, T., Warren, M. \& Settele J. (2013). Euphydryas aurinia. - IUCN 2013. IUCN Red List of Threatened Species. Version 2013.1. www.iucnredlist.org. Downloaded on 28 August 2013.

Vergeer, P., Rengelink, R., Copal, A. \& Ouborg N.J. (2003a). The interacting effects of genetic variation, habitat quality and population size on performance of Succisa pratensis. J. Ecol., 91(1), 18-26. http://www.jstor.org/ stable/3599533

Vergeer, P., Rengelink, R., Ouborg, N.J. \& Roelofs J.G.M. (2003b). Effects of population size and genetic variation on the response of Succisa pratensis to eutrophication and acidification. J. Ecol., 91(4), 600-609. http://www.jstor. org/stable/3599573

Wallin, L. (2007). Plant population dynamics and conservation in wooded hay-meadows - effects of intensified management. Acta Univ. Ups., 282, 1-35.

Winkler, E. \& Stöklin J. (2002). Sexual and vegetative reproduction of Hieracium pilosella L. under competition and disturbance: a Grid-based Simulation Model. Ann. Bot., 89(5), 525-536. DOI: 10.1093/aob/mcf075. 